\begin{tabular}{lcl}
\hline Bentham OPEN & Open Medicine Journal \\
CrossMark & Content list available at: www.benthamopen.com/MEDJ/ & $\begin{array}{l}\text { Open } \\
\text { Medicine } \\
\text { lournal }\end{array}$ \\
\hline
\end{tabular}

RESEARCH ARTICLE

\title{
HLA-G in Amerindians: Epidemiology and Worldwide Population Comparison
}

\author{
Antonio Arnaiz-Villena*, Mercedes Enriquez-de-Salamanca ${ }^{\$}$, Jose Palacio-Gruber, Ignacio Juarez, \\ Ester Muñiz, Jorge Nieto, Cristina Campos and Jose Manuel Martin-Villa \\ Department of Immunology, University Complutense, School of Medicine, The Madrid Regional Blood Center, Madrid, \\ Spain.
}

\begin{abstract}
:
Background:

HLA-G molecules are immunosuppressive and avoid fetal rejection by giving negative signals to maternal immune system from fetal trophoblast cell surface. HLA-G genes have been associated to different pathologies: Spontaneous abortions, autoimmunity, tumor progression, transplant rejection and infection. In addition, different World populations show remarkable different HLA-G allele frequencies in the allele that does not produce a full HLA-G molecule (HLA-G*05N); this allele is almost absent in studied Amerindians.
\end{abstract}

\section{Objectives:}

The aim is to study HLA-A.-B,-DRB1 and $-\mathrm{G}$ alleles and extended haplotypes in Amerindians for the first time. This may be useful to asses HLA-G epidemiology, association to disease and Preventive Medicine in Amerindians.

\section{Methods:}

HLA-A,-B and -DRB1 have been typed by using standard automatic protocols. HLA-G alleles have been detected by direct HLA-G exon 2, exon 3 and exon 4 DNA sequencing. Computer calculations have been done by specific standard methods.

\section{Results:}

HLA-A,-B,-DRB1 and $-\mathrm{G}$ extended haplotypes have been calculated in Amerindians for the first time. Also, their HLA-G frequencies have been compared with worldwide populations.

\section{Conclusion:}

Low frequencies of null HLA-G*01:05N allele are found in Amerindians. The extended haplotypes with this allele bear other typical Amerindian HLA-DRB1 alleles and its origin is discussed. HLA-G allele frequency profile is closer to that of Europeans than to that of Far East Asians. Our findings are useful to Preventive Medicine and Epidemiology associated to Fertility and HLA-G associated pathology and transplantation.

Keywords: Abortion, Amerindians, Autoimmunity, Epidemiology, Fertility, HLA-G, HLA-G*01:20, HLA-G*01:08:02, Immune Suppression, Population Genetics, Transplantation, Tumor.

\footnotetext{
* Address correspondence to this author at the Department of Immunology, University Complutense, School of Medicine, The Madrid Regional Blood Center, Madrid, Spain; Tel: +34 913941642/7080, +34 600993161; E-mail: arnaizantonio@gmail.com; URL: www.chopo.pntic.mec.es/biolmol ${ }^{\$}$ These authors contributed equally for this work and the order of authorship is arbitrary.
} 


\section{INTRODUCTION}

The First Native Americans are postulated to have populated America coming from Asia through the Bering land bridge between 30,000 and 12,000 years before present (BP). Siberia [1] and Mongolia [2, 3] have been thought as the most approximate places of Amerindians origin in Asia. A study [4] proposed the triple migration hypothesis for explaining the Americas peopling on linguistic bases: Amerindians (most North and South American Indians; 12,000 BP), Na-Dene (Athabascans, Navajo, Apache; 8000 BP) and Eskimo-Aleuts (6000 BP). However, Y chromosome markers established that more than one paternal founder haplotype arrived into America on different migration times [5, 6]. Alu insertions (also nuclear DNA) research [7]: suggest that the geographical distribution was the result of only one wave of immigration. In addition, East Asian HLA genes have been found in the Azores Islands [8]; is an evidence of spreading of Chinese fleet around the world in 1421 [9]. Also, South American peopling may have come from Asia or Polynesia because HTLV-1 virus strain shared identical DNA sequences in Japan and in the northern coast of South America [10] and some HLA alleles may have been exchanged by a Trans-Pacific route [11 - 14]. Both genetic [8] and archaeological [15] evidence suggest that two-way Trans-Atlantic traffic occurred before Europeans came to America in 1492 AD. Tools in New Mexico have recently found used 20,000 years ago in Spanish Solutrean culture [13 - 16]. Other prehistoric common artifacts to America and Europe have been described [17].

On the other hand, HLA-G proteins have been found to be tolerogenic MHC molecules. They were described being expressed in placental cytotrophoblast and have a role in fetal/maternal immunological tolerance [18] and also in disease like spontaneous abortions, tumor immunology, transplantation and autoimmunity [19]. However, HLA-G is also expressed normally in other tissues comprising cornea, adult thymic epithelial cells, erythroblasts, pancreatic islets, endothelial precursors and mesenchymal stem cells [20]. Its polymorphism is low compared to classical class I loci [21]. HLA-G surface protein has interactions with cell receptors of the immune system, including the killer cell immunoglobulin-like receptor KIR2DL4, CD8, LILRB1 and LILRB2 [22]. HLA-G*01:05N (first described in Spaniards [23]) is being maintained throughout time in World populations [24] and it was shown that homozygous HLA-G*01:05N females can normally give birth and that HLA-G*01:05N individuals are born without problems, and do not show at 30-40 years old any symptom of immunodeficiency, autoimmunity or tumor pathology [25].

Most Amerindian XXI century immigrants in Madrid come from Andean Countries (mainly Ecuador, Colombia, Peru and Bolivia). They show an HLA gene profile with "quasi-specific alleles", which makes them different to the rest of the World, and they never had been typed for HLA-G gene before. Recently, immigrated volunteer unrelated blood donors contributed to the present study [26].

Our aims are: 1) To analyze HLA-G allele frequencies in Amerindian immigrant healthy population to be used as a documented reference for future studies on HLA-G population variation allele frequency and its association with unexplained infertility and other disorders; 2) To analyze four loci (HLA-A, -B, -DRB1, -G) extended haplotypes frequencies and compare them with those of other worldwide populations in order to study the HLA relatedness with peoples most likely to be candidates for First American Peoples ancestors; 3) To analyze HLA-G*01:05N allele frequencies in our population in order to a precise view of HLA-G*01:05N allele frequency distribution throughout different World populations. Our results may be important in Amerindian-infections Epidemiology studies, their Preventive Medicine of fetal/mother normal and pathological relationships and other autoimmune, tumor or transplant pathologies.

\section{MATERIALS AND METHODS}

\subsection{Population Sample}

154 healthy unrelated Amerindian and Caribbean individuals were HLA-G typed [26]. Samples were collected from volunteer immigrant Amerindian blood donors at The Madrid Regional Blood Center. A written consent to participate in the present study was signed by each blood donor. Individuals were classified as Amerindian both by physical anthropology and by born place in an Andean or other Iberian-American country and their Amerindian origin was also assessed confirmed by full typing of HLA-A, -B, DRB1 and-DQB1 [11]. Only individuals who come from rural or tribal areas and whose grand-parents come from the same areas were used for the study. Individual country origin and number were the following ones: Ecuador, 45; Colombia, 42; Peru, 21; Bolivia, 10; Argentina, 7; Dominican Republic, 6; Brazil, 5; Mexico, 4; Uruguay, 4; Chile, 4; Paraguay, 2; Venezuela, 2; Honduras, 1; Nicaragua, 1; Cuba, 1 and Guatemala, 1 . 


\subsection{DNA Extraction, Amplification and HLA-G Sequencing}

Genomic DNA from peripheral blood nucleated cells was extracted with the Nucleic Acid Isolation System QuickGene-810 (Fujifilm, Japan) by using reagents and protocols provided by the manufacturer (QuickGene Whole Blood Extraction Kit S, Fujifilm, Japan).HLA-A,-B,-DRB1 alleles typing were obtained by a standard protocol [14]. HLA DNA amplification of exons 2, 3 and 4 of HLA-G was carried out separately by direct PCRs. In order to obtain each HLA-G exons sequences, the following specific 5' and 3' primers were used. Exon 2: forward: 5'GAGGGTCGGGCGGGTCTCAAC-3', reverse: 5'-GCATGGAGGTGGGGGTCGTGA-3'; Exon 3: forward 5'TGGGCGGGGCTGACCGAGAAGGTGG-3', reverse: 5'-CTCTCCTTGTGCTAGGCCAGGCTGAGA-3'; Exon 4: forward: 5'-CCATGAGAGATGCAAAGTGCT-3', reverse: 5'-TGCTTTCCCTAACAGACATGA-3'. The PCR conditions consisted of 1 cycle of $95^{\circ} \mathrm{C}, 15 \mathrm{~min} ; 95^{\circ} \mathrm{C}, 0.5 \mathrm{~min} ; 35$ cycles of $68^{\circ} \mathrm{C}, 0.5 \mathrm{~min} ; 72^{\circ} \mathrm{C}, 0.67 \mathrm{~min}$ and 1 cycle of $72^{\circ} \mathrm{C}, 10 \mathrm{~min}$ for the exon $2 ; 1$ cycle of $94^{\circ} \mathrm{C}, 2 \mathrm{~min} ; 94^{\circ} \mathrm{C}, 1 \mathrm{~min} ; 35$ cycles of $67^{\circ} \mathrm{C}, 1.5 \mathrm{~min} ; 72^{\circ} \mathrm{C}, 2 \mathrm{~min}$ and 1 cycle of $72^{\circ} \mathrm{C}, 10 \mathrm{~min}$ for the exon 3 ; and 1 cycle of $95^{\circ} \mathrm{C}, 5 \mathrm{~min} ; 95^{\circ} \mathrm{C}, 0.67 \mathrm{~min} ; 35$ cycles of $58^{\circ} \mathrm{C}, 0.67 \mathrm{~min} ; 72^{\circ} \mathrm{C}$, $0.67 \mathrm{~min}$ and 1 cycle of $72^{\circ} \mathrm{C}, 10 \mathrm{~min}$ for the exon 4 , in a programmable heat block (Mastercycler epgradient $\mathrm{S}$, Eppendorf, Germany). The obtained products were electrophoresed in a $2 \%$ agarose and detected by staining with Olerup SSP Gelred and were purified by using the Mini Elute Gel Extraction Kit 250, QIAGEN. Purified products were DNA sequenced using the ABI 3730 DNA analyzer (Applied Biosystems, Foster City, CA, USA) by using the same primers of amplification process. HLA-A,-B,-DRB1 typings were obtained by a standard protocol [14]. DNA HLA-G polymorphism was identified by aligning the sequences with identified alleles [21] using Mega 5 software [27].

\subsection{Statistical Analyses}

HLA-G allele frequencies in Amerindians were calculated with Arlequin 3.0 computer program [28], kindly provided by the author. This program was also used to test the Hardy-Weinberg equilibrium [29, 30].

\section{RESULTS}

\subsection{HLA-G allele Frequencies in Amerindian Population from Madrid}

18 of the 51 HLA-G alleles described [21] are present in our Amerindian population (Table 1). The three most frequent alleles are: HLA-G*01:01:01 (31.2\%); HLA-G*01:01:02 (23.1\%) and HLA-G*01:04:01 (12.8). The HLA$\mathrm{G}^{*} 01: 05 \mathrm{~N}$ null allele is present in a frequency of $1.3 \%$.

Table 1. HLA-G allele frequencies in Amerindian population.

\begin{tabular}{|c|c|c|c|}
\hline HLA-G alleles & Allele Frequency (\%) & HLA-G alleles & Allele Frequency (\%) \\
\hline HLA-G*01:01:01 & 31.2 & HLA-G*01:01:19 & 0.4 \\
\hline HLA-G*01:01:02 & 23.1 & HLA-G*01:01:20 & 1.3 \\
\hline HLA-G*01:01:03 & 4.3 & HLA-G*01:03:01 & 7.7 \\
\hline HLA-G*01:01:05 & 0.9 & HLA-G*01:04:01 & 12.8 \\
\hline HLA-G*01:01:06 & 2.1 & HLA-G*01:04:03 & 1.7 \\
\hline HLA-G*01:01:07 & 0.4 & HLA-G*01:04:04 & 3.8 \\
\hline HLA-G*01:01:08 & 3.0 & HLA-G*01:04:05 & 0.4 \\
\hline HLA-G*01:01:15 & 0.4 & HLA-G*01:05N & 1.3 \\
\hline HLA-G*01:01:17 & 0.9 & HLA-G*01:06 & 0.4 \\
\hline
\end{tabular}

\subsection{Haplotypes in Amerindian Population from Madrid}

Frequencies of two loci (HLA-A-B) and four loci (HLA-A-B-DRB1-G) HLA haplotypes were calculated. Results are shown in Tables 2 and 3. Results of the closest HLA studied locus to HLA-G (i.e.: HLA-A) are shown in Table 2.

Table 2. HLA two loci haplotype frequencies in Amerindian population.

\begin{tabular}{|c|c|c|c|}
\hline HLA-A-G & HF (\%) & HLA-A-G & HF (\%) \\
\hline $\mathrm{A}^{*} 02: 01-\mathrm{G} * 01: 01$ & 24.6 & $\mathrm{~A} * 01: 01-\mathrm{G} * 01: 06$ & 3.3 \\
\hline $\mathrm{A} * 24: 02-\mathrm{G} * 01: 04$ & 13.2 & $\mathrm{~A} * 68: 02-\mathrm{G} * 01: 01$ & 2.9 \\
\hline $\mathrm{A} * 3: 01-\mathrm{G} * 01: 01$ & 6.6 & $\mathrm{~A} * 32: 01-\mathrm{G} * 01: 01$ & 2.9 \\
\hline $\mathrm{A} * 68: 01-\mathrm{G} * 01: 01$ & 5.2 & $\mathrm{~A} * 30: 02-\mathrm{G} * 01: 01$ & 2.4 \\
\hline
\end{tabular}


(Table $\square$ ) contd.....

\begin{tabular}{|c|c|c|c|}
\hline HLA-A-G & HF (\%) & HLA-A-G \\
\hline A*29:02-G*01:01 & 5.0 & A*26:01-G*01:01 \\
\hline A*23:01-G*01:04 & 3.3 & A*30:01-G*01:05N & 2.4 \\
\hline A*11:01-G*01:01 & 3.3 & A*31:01-G*01:05N & 0.8 \\
\hline A*02:11-G*01:01 & 3.3 & 0.4 & \\
\hline
\end{tabular}

HF: Haplotype frequency

The 13 two loci most frequent HLA-A-G haplotypes are depicted in Tabel 2 . Two of the haplotypes contain the null allele HLA-G*01:05N. A*30:01-G*01:05N goes either with $B^{* 45: 05}$ or $B^{*} 45: 01$ and $A * 31: 01-G^{*} 01: 05 \mathrm{~N}$ goes with $B^{*} 15: 05$. $A * 02: 01-G^{*} 01: 01(24.6 \%)$ and $A * 24: 02-G^{*} 01: 04(13.2 \%)$ are the two loci haplotypes with higher frequencies.

Table 3. HLA four loci haplotype frequencies in Amerindian population.

\begin{tabular}{|c|c|c|}
\hline HLA-A-B-DRB1-G & HF (\%) & Also found in \\
\hline$A * 24: 02-B * 35: 01-D R B 1 * 14: 02-G^{*} 01: 04^{a}$ & 2.9 & Amerindian \\
\hline A*02:01-B*35:04-DRB1*08:02-G*01:01 ${ }^{\mathrm{b}}$ & 1.7 & Amerindian \\
\hline$A * 02: 01-B * 40: 02-D R B 1 * 04: 07-G * 01: 01^{c}$ & 1.2 & Amerindian \\
\hline $\mathrm{A}^{*} 03: 01-\mathrm{B}^{*} 07: 02-\mathrm{DRB} 1 * 15: 01-\mathrm{G}^{*} 01: 01^{\mathrm{d}}$ & 1.2 & North Africans,Europeans \\
\hline A*02:01-B*44:03-DRB1*13:02-G*01:01 $1^{\mathrm{e}}$ & 1.2 & Italian, German, Japanese \\
\hline A*03:01-B*51:01-DRB1*04:04-G*01:01 $1^{\mathrm{f}}$ & 1.2 & German \\
\hline A*24:02-B*14:02-DRB1*07:01-G*01:01 ${ }^{\mathrm{g}}$ & 1.2 & German \\
\hline A*68:01-B*40:04-DRB1*04:03-G*01:01 ${ }^{\mathrm{h}}$ & 1.2 & Venezuelan (probably Amerindian) \\
\hline A*31:01-B*39:06-DRB1*13:02-G*01:01 ${ }^{\mathrm{i}}$ & 1.2 & New \\
\hline$A * 29: 02-B * 15: 05-D R B 1 * 04: 03-G * 01: 05 N^{j}$ & 0.6 & New \\
\hline $\mathrm{A}^{*} 31: 01-\mathrm{B} * 15: 05-\mathrm{DRB} 1 * 04: 03-\mathrm{G}^{*} 01: 05 \mathrm{~N}^{\mathrm{k}}$ & 0.6 & New \\
\hline A*33:03-B*57:03-DRB1*13:02-G*01:05 ${ }^{1}$ & 0.6 & New \\
\hline
\end{tabular}

HF: Haplotype frequency. a: This haplotype without HLA-G is found in Aymara, Quechua and Jaydukama populations [31 - 33]. b: This haplotype without HLA-G is found in Aymara, Mayo, Mayans, Quechua, Wayu and Nahua populations [31, 32, 34 - 37]. c: This haplotype without HLA-G is found in Aymara, Mayo, Jaidukama and Lama populations [31, 33, 34, 38]. d: This haplotype without HLA-G is found in Occidental Europe populations and Chuvasian [39, 40]. e: This haplotype is found in low frequency in Italian, German and Japanese populations [41]. f: This haplotype is found in low frequency in German population [41]. $\mathrm{g}$ : This haplotype is found in low frequency in German population [41]. h: This haplotype is found in low frequency in Venezuelan population [41]. $\mathrm{i}$ : This haplotype is not found in any other population. $\mathrm{j}$ : This haplotype is not found in any other population. $\mathrm{k}$ : This haplotype is not found in any other population. 1: This haplotype is not found in any other population.

The most frequent four loci haplotype in our Amerindian population is A*24:02-B*35:01-DRB1*14:02-G*01:04 with a frequency of $2.9 \%$ (Table 3). This haplotype is found without HLA-G locus in other populations, such as, Aymara, Quechua and Jaidukama (see Table 3 footnote for references). Two alleles of this haplotype, HLA-A*24:02 and HLA-G*01:04 are in linkage disequilibrium in our studied population ( Table 2). The second most frequent four loci haplotype is $A^{*} 02: 01-B^{*} 35: 04-D R B 1 * 08: 02-G^{*} 01: 01$ with a frequency of $1.7 \%$ (Table 3). This haplotype without HLA-G locus is also found in other Amerindian populations, such as, Mayan, Aymara, Quechua, Mayos, Nahua and Wayu (see Table 3 footnote for references). Two alleles of this haplotype, HLA-A*02:01 and HLA-G*01:01, are in linkage disequilibrium (data not shown) in our population.

In Table 3, it can be observed that the most frequent haplotypes without HLA-G locus have a possible Amerindian origin. There is a certain European influence, that can be observed in the haplotype A*03:01-B*07:02-DRB1*15:01$G^{*}$ 01:01, since this haplotype has a possible European or North African origin and has a high frequency in North Spain populations [40] and Irish populations [41]. The first most frequent Amerindian four loci extended haplotypes bear HLA-G*01:04 allele. The last four haplotypes A*31:01-B*39:06-DRB1*13:02-G*01:01, A*29:02-B*15:05DRB1*04:03-G*01:05N, A*31:01-B*15:05-DRB1*04:03-G*01:05N and A*33:03-B*57:03-DRB1*13:02-G*01:05N have not been found in any other populations (see Table 3 footnote for details).

\subsection{Null Allele, HLA-G*01:05N, in Amerindian Population from Madrid}

Three null alleles were found in three different individuals, each of them from a different country, i.e.: Colombia, Argentina and Nicaragua. The HLA-G*01:05N frequency was $1.3 \%$ as it shows in Table 1. Other populations that show low frequency of null allele HLA-G*01:05N are mixed Brazilians, Amerindian Uros and Amerindian Mayans. On the 
other hand, the highest null allele frequencies are observed in Middle East populations, such as, North Indians, Iranians and Iraqi and in African populations except Pygmies, such as, Ghanaian, African American and Shona. These six populations that present high frequencies of null allele, have significant frequency differences compared with our studied population of Amerindians from Madrid by Fisher Test with a $p$ value $<0.05$.

\section{DISCUSSION}

\subsection{HLA-G Polymorphism in Our Amerindian Sample}

A characteristic of HLA-G is its low polymorphism. It is suggested that it could be due to its tolerogenic and not presentation function. Most of HLA-G alleles have been found to be silent mutations in exons/introns [41, 42]. However, many of HLA-G alleles have been described only in one study, since they have not been found in other populations [41]. Asian, African and Caucasoid populations have a low HLA-G allelic variability compared with the rest of classic class I HLA genes [41, 43]. Amerindian populations have in common the limited number of classic class I HLA alleles [38]. Regarding to non classic class I HLA alleles, as HLA-G, there are only a few studies about their frequencies in these populations $[41,44,45]$.

Only four HLA-G different proteins are usually typed in World populations. These proteins are encoded by most frequent groups of HLA-G alleles, such as, HLA-G*01:01, G*01:03, G*01:04 y G*01:06, which could be different regarding HLA-G function [19]. Eighteen different DNA alleles have been detected in the studied population, being the most frequent HLA-G*01:01:01 with a frequency of 31.2\%. This low numbers are concordant to those found in Brazil, China, Ghana, Poland and Korea and others [41]. Eleven different alleles within the HLA-G*01:01 group of alleles; have been, while four alleles have been detected in HLA-G*01:04 group (see Table 1). In other populations the number of HLA-G alleles is very limited (Koreans [46], Shona African [47] and Danish [48]). However, the number of alleles in our population is relatively high as also found in Brazilians [45]. The lack of worldwide exchange and international HLA-G workshops may be the cause of the observed low polymorphism and in the future HLA-G may show to be as polymorphic as other HLA class I locus.

Two new HLA-G alleles have been described in our studied Amerindians sample [49]. One new allele was found in a male individual from Ecuador, with the following GenBank accession number: KP739973; it was named HLA$\mathrm{G}^{*}$ 01:08:02 by the IMGT/HLA database $[21,49,50]$. The other new allele was found in a female individual from Hispaniola Island (Sto Domingo); its GenBank accession number is KP739974. The IMGT/HLA database named it as HLA-G*01:20 [21, 49, 50].

\subsection{Analyses of Extended Haplotypes in Amerindian Population}

In the present study, four loci (HLA-A-B-DRB1-G) extended haplotype have been calculated (see Table 3). The most frequent extended haplotypes in the studied population are shown in Table 3 . The three first are $A^{*} 24: 02-$ B*35:01-DRB1*14:02-G*01:04, A*02:01-B*35:04-DRB1*08:02-G*01:01 and A*02:01-B*40:02-DRB1*04:07$\mathrm{G}^{*} 01: 01$ with a frequency of $2.9 \%, 1.7 \%$ and $1.2 \%$ respectively. These haplotypes without HLA-G locus are characteristic of Amerindian and have also been observed in Aymara [31], Quechua [32], Jaidukama [33], Mayan [35], Nahua [37], Wayu [36], Lama [38] and Mayo [34] populations. Two of these haplotypes, A*24:02-B*35:01DRB1*14:02-G*01:04 and A*02:01-B*35:04-DRB1*08:02-G*01:01 bear DRB1*08:02 and DRB1*14:02 alleles which are considered "quasi specific" markers of Amerindian populations [51, 52]. In addition, haplotype A*02:01B*40:02-DRB1*04:07-G*01:01 bears DRB1*04:07 allele, which is also observed in Amerindians [38].

The Amerindian HLA profile is different compared to the rest of World [11 - 14, 53 - 55], and it is confirmed in our present study; HLA-A*03:01-B*07:02-DRB1*15:01-G*01:01 haplotype has a possible North African or European origin (see Table 3). This haplotype has been found without HLA-G in high frequency in North Spain populations [40] and also in northern European populations [41].

The last four extended haplotypes in Table $\mathbf{3}$ have been not been found in any other population.

\subsection{HLA-G*01:05N in Amerindians: Comparison with Worldwide Populations}

Three null alleles were detected in three different individuals, all of them heterozygous (Tables 1 and 2). In 1997, the first null allele of HLA-G locus was described by us in a Spanish population sample [23]. This null allele permitted transcription and translation of HLA-G isoforms bearing only alpha-1 domain. Exon 3 is removed by a previous DNA base deletion and a consequent shifting of reading frame which generates a stop codon $[19,23,56]$. Frequencies of Uros 
(from the Titikaka Lake) and Mayas (from Guatemala) null allele were very similar to those found now by us. This null allele has been associated with spontaneous and recurrent abortions and, in the other hand, also with a protective effect against intrauterine infections during the gestation [19,44]. The absolute absence of null allele both in Uros and Mayas contradicts the hypothesis that frequent intrauterine infections can maintain null allele frequencies, since health care in Amerindian communities is and has been poor, comparatively to European ones. Also, Amerindian admixed Brazilian population show similar results [45]. Populations with a significantly higher HLA-G*01:05N frequency include some Middle East Caucasians (Iraqis, Iranians, Indians from North India) and certain African populations (Ghana, Shona and African Americans) (Fig. 1).

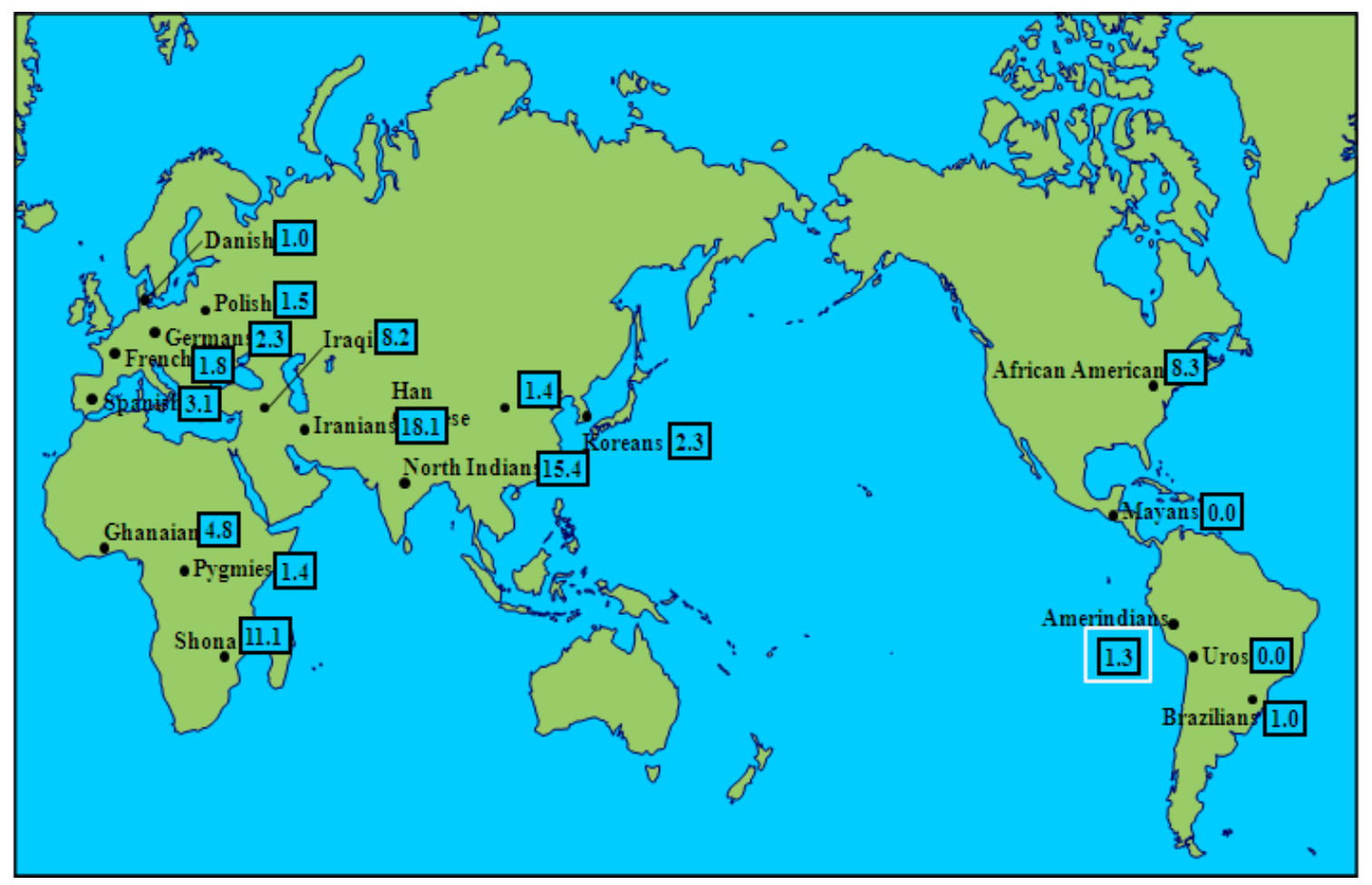

Fig. (1). World distribution map of null allele HLA-G*01:05N. Frequencies of each population are shown in the boxes. References of each population: Amerindians: present study (white square). See materials and Methods section for specific subjects origin, since not all of them come from Andean area. Brazilians [41], Uros [44], Mayans [44], North Indians [57], Iranians [58], Iraqi [59], Danish [48], Spanish [23], Germans [60], French [61], Polish [62], Han Chinese [63], Koreans [46], Ghanaian [64], African American [64], Pygmies [61], Shona [47].

HLA-G*01:05N allele DNA sequence may indicate that it was originated from the HLA-G*01:01:02 allele, following the deletion of the cysteine at the 129/130 codon, since its sequences are identical, except for such deletion [25]. In addition, HLA-G* 01:05N is associated with the HLA-A*30:01-B*13:02 haplotype prevalent in the Middle East and some Mediterranean populations, as it may have been introduced in Spain by Berber/Muslim invaders in the 8th century $\operatorname{AD}[13,14,23]$, or when the Mediterranean glacial refugee was established around 10,000 BC [65, 66], which could place the Middle East as the origin of this mutation [44].

Regarding the extended haplotypes studied, three of the entire list of haplotypes obtained carried the null allele; HLA-A*33:03-B*57:03-DRB1*13:02-G*01:05N, HLA-A*31:01-B*15:05-DRB1*04:03-G*01:05N and HLAA*29:02-B*15:05-DRB1*04:03-G*01:05N (Table 3), which still shows the low presence of this allele in Amerindian populations. These three haplotypes have not been found in any other population (Table $\mathbf{3}$ and footnote). They are in part Amerindian since DRB1 alleles were typical Amerindian [11]. HLA-B*15:05 allele has a possible Amerindian origin [41], and two of the extended haplotypes carry this allele, HLA-A*31:01-B*15:05-DRB1*04:03-G*01:05N and HLA-A*29:02-B*15:05-DRB1*04:03-G*01:05N (Table 3). HLA-B*57:03 allele has a possible African, Caucasoid origin [41] and is it observed in the extended haplotype HLA-A*33:03-B*57:03-DRB1*13:02-G*01:05N. Linkage disequilibrium may be mainly indicative of a population admixture in that region [67], so it could be understood that there has been a low degree of admixture in the studied Amerindian population, probably with Europeans and Africans. 
The existence of "diseased" genes in a population is often justified by evolutionary advantages. As discussed above, the HLA-G immunosuppressive molecule plays a major role in the fetus's acceptance of the mother during gestation [19]. The maternal-fetal interests may become contradictory due to lower levels of HLA-G, the mother's immune system could cause fetal damage and finally spontaneous abortions in heterozygous or healthy homozygous mothers for the HLA-G*01:05N allele [44]. However, it was observed that women and fetuses of the same Spanish family, homozygous for the HLA $-\mathrm{G}^{*} 01: 05 \mathrm{~N}$ allele, were healthy individuals capable of having completely normal deliveries and being born, indicating that the HLA-G1 isoform is not essential for survival [25]. This is further supported by the findings that genus Macacca primates survive healthy with HLA-G incomplete molecules, due to a DNA deletion [68, 69]. Protective effects of this allele have been described against intrauterine infections in pregnant women. It is unclear, but both circumstances could coexist [44]. The presence of this null allele in the population could be due to the fact that the $\alpha 1$ domain is sufficient for the normal functioning of the HLA-G molecule, so negative evolutionary forces would not act to eliminate this gene. Other advantages than avoiding maternal rejection of fetus may be attributed to this null allele: HLA-G*01:05N allele also may provide some selective advantage, not only maternal-fetal, but to improve the level of immune response against HIV infection [70] or other infections of the immune system not directly related to pregnancy.

\subsection{HLA-G*01:04 and HLA-G*01:01 Allele Frequencies in Amerindians and Worldwide Populations}

The highest frequencies of HLA-G*01:04 allele are found in Japanese, Iranian and South Korean populations (45\%, $29.4 \%$ and $27.7 \%$ respectively) (Fig. 2). Our Amerindian population has a frequency of $18.7 \%$. Other Amerindian populations have similar frequencies to that found in our present sample, such as Uros from Titikaka Lake with a frequency of $10.2 \%$ and Mayans from Guatemala with a $13.1 \%$. It is important to highlight that has not been detected any population with a frequency of this allele higher than $10 \%$ in central Europe and higher than $13 \%$ in Iberia (Portuguese 13\%, Spaniards 11\%, (Fig. 2). Significant HLA-G frequency differences have not been found between Amerindians and the rest of World populations (results not shown), but only a trend to lower frequency in central Europe is observed.

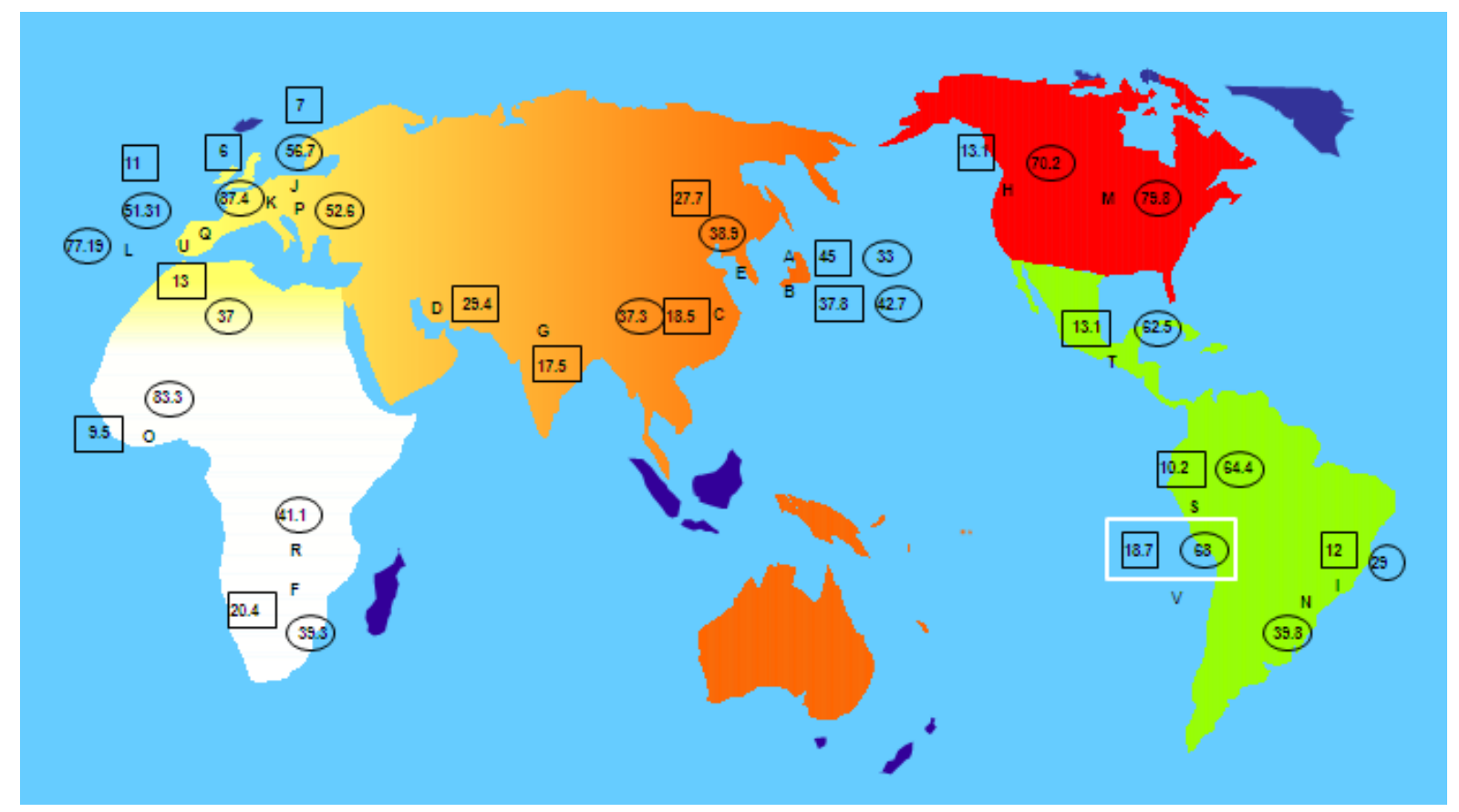

Fig. (2). World population's frequency pattern of HLA-G*01:04 and HLA-G*01:01 alleles. HLA-G*01:04 allele frequencies are marked by a square and HLA-G*01:01 allele frequencies are marked by a circle. Allele frequencies of each population and references are specified below.

A- Japan pop 14: G*01:04 $\rightarrow 45 \%, \mathrm{G}^{*} 01: 01 \rightarrow 33 \%[71]$

B- Japan pop 15: $\mathrm{G}^{*} 01: 04 \rightarrow 37.8 \%, \mathrm{G}^{*} 01: 01 \rightarrow 42.7 \%$ [64]

C- China Zhejiang Province Han: $\mathrm{G}^{*} 01: 04 \rightarrow 18.5 \%$, G*01:01 $\rightarrow 37.3 \%$ [63]

D- Iran Tehran pop 2: G*01:04 $\rightarrow 29.4 \%$ [58]

E- South Korea pop 7: G*01:04 $\rightarrow 27.7 \%, G^{*} 01: 01 \rightarrow 38.9 \%$ [72] 
F- Zimbabwe Harare Shona pop 2: G*01:04 $\rightarrow 20.4 \%, G^{*} 01: 01 \rightarrow 39.3 \%$ [73]

G- India Lucknow pop 2: $\mathrm{G}^{*} 01: 04 \rightarrow 17.5 \%$ [57]

H- USA African American pop 6: G*01:04 $\rightarrow 13.1 \%, G^{*} 01: 01 \rightarrow 70.2 \%$ [64]

I- Brazil Parana mixed: G*01:04 $\rightarrow 12 \%, \mathrm{G}^{*} 01: 01 \rightarrow 29 \%$ [74]

J- Denmark pop2: $\mathrm{G}^{*} 01: 04 \rightarrow 7 \%[75], \mathrm{G}^{*} 01: 01 \rightarrow 56.7 \%[76]$

K- Germany pop5: $\mathrm{G}^{*} 01: 04 \rightarrow 6 \%, \mathrm{G}^{*} 01: 01 \rightarrow 87.4 \%[60]$

L- Portugal Azores Terceira Island: $G^{*} 01: 01 \rightarrow 77.19 \%$ [41]

M- USA South Dakota Hutteritie: G*01:01 $\rightarrow 79.8 \%$ [77]

N- Brazil Sao Paulo pop 2: G*01:01 $\rightarrow 39.8 \%$ [45]

O- Ghana: $\mathrm{G}^{*} 01: 04 \rightarrow 9.5 \%, \mathrm{G}^{*} 01: 01 \rightarrow 83.3 \%$ [64]

P- Poland pop 2: $\mathrm{G}^{*} 01: 01 \rightarrow 52.6 \%$ [62]

Q- Spain pop 2: $\mathrm{G}^{*} 01: 04 \rightarrow 11 \%, \mathrm{G}^{*} 01: 01 \rightarrow 51.31 \%[23]$

R- Zambia: $\mathrm{G}^{*} 01: 01 \rightarrow 41.1 \%$ [78]

S- Titikaka Lake Uros: $\mathrm{G}^{*} 01: 04 \rightarrow 10.2 \%, \mathrm{G}^{*} 01: 01 \rightarrow 64.4 \%$ [44]

T- Guatemala Mayans: $\mathrm{G}^{*} 01: 04 \rightarrow 13.1 \%, \mathrm{G}^{*} 01: 01 \rightarrow 62.5 \%$ [44]

U- Portuguese: $G^{*} 01: 04 \rightarrow 13 \%, G^{*} 01: 01 \rightarrow 37 \%$ [79]

V- Amerindians from Madrid: $G^{*} 01: 04 \rightarrow 18.7 \%, G^{*} 01: 01 \rightarrow 68 \%$ (present study)

Regarding to [2] HLA-G*01:01 allele, the highest frequencies are found in Germany, Ghana and USA South Dakota Hutteritie populations $(87.4 \%, 83.3 \%$ and $79.8 \%$ respectively). Our studied Amerindian population has a frequency of $68 \%$, very similar to other Amerindian populations, such as, Uros from Titikaka Lake and Mayans from Guatemala, (64.4\% and 62.5\% respectively). Significant differences have not been found between Amerindians and the rest of World populations (results not shown), only a trend to a higher frequencies in Germany and Africa (Ghana) (Fig. 2).

\section{CONCLUSION}

Present study results may be important in the field of epidemiology studies of infection, abortions, infertility and fetal pathology and Preventive Medicine at the maternal-fetal relationship.

\section{ETHICS APPROVAL AND CONSENT TO PARTICIPATE}

Not applicable.

\section{HUMAN AND ANIMAL RIGHTS}

No Animals/Humans were used for studies that are base of this research.

\section{CONSENT FOR PUBLICATION}

Not applicable.

\section{CONFLICT OF INTEREST}

The authors declare no conflict of interest, financial or otherwise.

\section{ACKNOWLEDGEMENTS}

This work was supported in part by Grants from the Spanish Ministry of Health and Economy PI14/01067 and European FEDER funds. We declare that these results have been fully obtained in our department without any external conflict of interest.

\section{RFERENCES}

[1] Crawford MH. The Origins of Native Americans: Evidence from anthropological genetics. revised ed.. UK: Cambridge University Press 1998.

[http://dx.doi.org/10.1017/CBO9780511574658]

[2] Kolman CJ, Sambuughin N, Bermingham E. Mitochondrial DNA analysis of Mongolian populations and implications for the origin of New World founders. Genetics 1996; 142(4): 1321-34. [PMID: 8846908]

[3] Merriwether DA, Hall WW, Vahlne A, Ferrell RE. mtDNA variation indicates Mongolia may have been the source for the founding population for the New World. Am J Hum Genet 1996; 59(1): 204-12. 
[PMID: 8659526]

[4] Greenberg JH, Turner CG, Zegura SL. The settlement of the Americas: A comparison of the linguistic, dental and genetic evidence. Curr Anthropol 1986; 27: 477-97.

[http://dx.doi.org/10.1086/203472]

[5] Karafet TM, Zegura SL, Posukh O, et al. Ancestral Asian source(s) of new world Y-chromosome founder haplotypes. Am J Hum Genet 1999; 64(3): 817-31.

[http://dx.doi.org/10.1086/302282] [PMID: 10053017]

[6] Santos FR, Pandya A, Tyler-Smith C, et al. The central Siberian origin for native American Y chromosomes. Am J Hum Genet 1999; 64(2): 619-28. [http://dx.doi.org/10.1086/302242] [PMID: 9973301]

[7] Novick GE, Novick CC, Yunis J, et al. Polymorphic Alu insertions and the Asian origin of Native American populations. Hum Biol 1998; 70(1): 23-39.

[PMID: 9489232]

[8] Bruges-Armas J, Martinez-Laso J, Martins B, et al. HLA in the Azores Archipelago: Possible presence of Mongoloid genes. Tissue Antigens 1999; 54(4): 349-59. [http://dx.doi.org/10.1034/j.1399-0039.1999.540404.x] [PMID: 10551418]

[9] Menzies G. 1421: The year China discovered the world. USA: Bantam 2002.

[10] Leon-S FE, Ariza-Deleon A, Leon-S ME, Ariza GA. Peopling the Americas. Science 1996; 273(5276): 723-5. [http://dx.doi.org/10.1126/science.273.5276.723] [PMID: 8701319]

[11] Arnaiz-Villena A, Areces C, Enriquez-de-Salamanca M, et al. Pacific Islanders and Amerindian relatedness according to HLA autosomal genes. Int J Mod Anthrop 2014; 1: 44-67.

[http://dx.doi.org/10.4314/ijma.v1i7.2]

[12] Arnaiz-Villena A, Areces C, Gomez-Prieto P, et al. The peopling of the Americas: A complex issue for Amerindian, Na-dene, Aleut and Eskimo first inhabitants. Int J Mod Anthrop 2010; 3: 65-79.

[13] Arnaiz-Villena A, Muñiz E, del Palacio-Gruber J, et al. Ancestry of Amerindians and its impact in anthropology, transplantation, HLA pharmacogenomics and epidemiology by HLA study in Wiwa Colombian population. Open Med J 2016; 3: $269-85$. [http://dx.doi.org/10.2174/1874220301603010269]

[14] Arnaiz-Villena A, de Palacio-Grüber J, Muñiz E, et al. HLA genes in Chimila Amerindians (Colombia), the Peopling of America and Medical implications Int J Mod Anthrop 2016; 1(9): 91-116.

[15] Holden C. Were Spaniards among the first Americans? Science 1999; 286(5444): 1467-8. [PMID: 10712138]

[16] Stanford DJ, Bradley BA. Across Atlantic ice: the origins of America's Clovis Culture. California, USA: University of California Press 2012.

[17] Arnaiz-Villena A, Alonso-Rubio J, Ruiz-del-Valle V. Tiwanaku (Titikaka Lake, Bolivia) and Alberite Dolmen (Southern Spain) ritual “ears”. Celtic, Iberian, Aymara and Basque languages. Int J Mod Anthrop 2013; 6: 61-76.

[http://dx.doi.org/10.4314/ijma.v1i6.3]

[18] Carosella ED, Moreau P, Le Maoult J, Le Discorde M, Dausset J, Rouas-Freiss N. HLA-G molecules: From maternal-Fetal tolerance to tissue acceptance. Adv Immunol 2003; 81: 199-252. [http://dx.doi.org/10.1016/S0065-2776(03)81006-4] [PMID: 14711057]

[19] Donadi EA, Castelli EC, Arnaiz-Villena A, Roger M, Rey D, Moreau P. Implications of the polymorphism of HLA-G on its function, regulation, evolution and disease association. Cell Mol Life Sci 2011; 68(3): 369-95.

[http://dx.doi.org/10.1007/s00018-010-0580-7] [PMID: 21107637]

[20] Rizzo R, Vercammen M, van de Velde H, Horn PA, Rebmann V. The importance of HLA-G expression in embryos, trophoblast cells, and embryonic stem cells. Cell Mol Life Sci 2011; 68(3): 341-52. [http://dx.doi.org/10.1007/s00018-010-0578-1] [PMID: 21080028]

[21] Robinson J, Halliwell JA, Hayhurst JD, Flicek P, Parham P, Marsh SG. The IPD and IMGT/HLA database: Allele variant databases. Nucleic Acids Res 2015; 43(Database issue): D423-31. [http://dx.doi.org/10.1093/nar/gku1161] [PMID: 25414341]

[22] Shiroishi M, Kuroki K, Rasubala L, et al. Structural basis for recognition of the nonclassical MHC molecule HLA-G by the leukocyte Ig-like receptor B2 (LILRB2/LIR2/ILT4/CD85d). Proc Natl Acad Sci USA 2006; 103(44): 16412-7.

[http://dx.doi.org/10.1073/pnas.0605228103] [PMID: 17056715]

[23] Suárez MB, Morales P, Castro MJ, et al. A new HLA-G allele (HLA-G*0105N) and its distribution in the Spanish population. Immunogenetics 1997; 45(6): 464-5. [http://dx.doi.org/10.1007/s002510050235] [PMID: 9089111]

[24] Larsen MH, Hviid TV. Human leukocyte antigen-G polymorphism in relation to expression, function, and disease. Hum Immunol 2009; 70(12): 1026-34.

[http://dx.doi.org/10.1016/j.humimm.2009.07.015] [PMID: 19651180] 
[25] Casro MJ, Morales P, Rojo-Amigo R, et al. Homozygous HLA-G*0105N healthy individuals indicate that membrane-anchored HLA-G1 molecule is not necessary for survival. Tissue Antigens 2000; 56(3): 232-9. [http://dx.doi.org/10.1034/j.1399-0039.2000.560305.x] [PMID: 11034559]

[26] Parga-Lozano C, Rey-Medrano D, Gomez-Prieto P, et al. HLA genes in Amerindian immigrants to Madrid (Spain): Epidemiology and a virtual transplantation waiting list: Amerindians in Madrid (Spain). Mol Biol Rep 2011; 38(4): 2263-71. [http://dx.doi.org/10.1007/s11033-010-0357-y] [PMID: 20931290]

[27] Tamura K, Peterson D, Peterson N, Stecher G, Nei M, Kumar S. MEGA5: Molecular evolutionary genetics analysis using maximum likelihood, evolutionary distance, and maximum parsimony methods. Mol Biol Evol 2011; 28(10): 2731-9. [http://dx.doi.org/10.1093/molbev/msr121] [PMID: 21546353]

[28] Excoffier L, Laval G, Schneider S. Arlequin (version 3.0): An integrated software package for population genetics data analysis. Evol Bioinform Online 2007; 1: 47-50. [PMID: 19325852]

[29] Imanishi T, Akaza T, Kimura A, Tokunaga K, Gojobori T. Allele and haplotype frequencies for HLA and complement loci in various ethnic groups.HLA 1991. Oxford, UK: Oxford University Press 1992; pp. 1065-220.

[30] Imanishi T, Akaza T, Kimura A, Tokunaga K, Gojobori T. Estimation of allele and haplotype frequencies for HLA and complement loci. In: Tsuji K, Aizawa M, Sasazuki T, Eds. HLA 1991. Oxford, UK: Oxford University Press 1992; pp. 76-9.

[31] Arnaiz-Villena A, Siles N, Moscoso J, et al. Origin of Aymaras from Bolivia and their relationship with other Amerindians according to HLA genes. Tissue Antigens 2005; 65(4): 379-90. [http://dx.doi.org/10.1111/j.1399-0039.2005.00356.x] [PMID: 15787722]

[32] Martinez-Laso J, Siles N, Moscoso J, et al. Origin of Bolivian Quechua Amerindians: Their relationship with other American Indians and Asians according to HLA genes. Eur J Med Genet 2006; 49(2): 169-85. [http://dx.doi.org/10.1016/j.ejmg.2005.04.005] [PMID: 16530714]

[33] Martinez-Laso J, Montoya F, Areces C, et al. HLA in Jaidukama: An Amerindian secluded Colombian population with new haplotypes and Asian and Pacific-Shared alleles. Mol Biol Rep 2011; 38(6): 3689-701. [http://dx.doi.org/10.1007/s11033-010-0483-6] [PMID: 21110114]

[34] Arnaiz-Villena A, Moscoso J, Granados J, et al. HLA Genes in Mayos Population from Northeast Mexico. Curr Genomics 2007; 8(7): 466-75. [http://dx.doi.org/10.2174/138920207783591735] [PMID: 19412332]

[35] Gómez-Casado E, Martínez-Laso J, Moscoso J, et al. Origin of Mayans according to HLA genes and the uniqueness of Amerindians. Tissue Antigens 2003; 61(6): 425-36.

[http://dx.doi.org/10.1034/j.1399-0039.2003.00040.x] [PMID: 12823766]

[36] Silvera C, Vargas-Alarcon G, Areces C, et al. HLA genes in Wayu Amerindians from Colombia. Immunol Invest 2011; 40(1): 92-100. [http://dx.doi.org/10.3109/08820139.2010.517390] [PMID: 20923327]

[37] Vargas-Alarcon G, Moscoso J, Martinez-Laso J, et al. Origin of Mexican Nahuas (Aztecs) according to HLA genes and their relationships with worldwide populations. Mol Immunol 2007; 44(5): 747-55.

[http://dx.doi.org/10.1016/j.molimm.2006.04.014] [PMID: 16765444]

[38] Moscoso J, Seclen S, Serrano-Vela JI, et al. HLA genes in Lamas Peruvian-Amazonian Amerindians. Mol Immunol 2006; 43(11): 1881-9. [http://dx.doi.org/10.1016/j.molimm.2005.10.013] [PMID: 16337001]

[39] Arnaiz-Villena A, Martinez-Laso J, Moscoso J, et al. HLA genes in the Chuvashian population from European Russia: Admixture of Central European and Mediterranean populations. Hum Biol 2003; 75(3): 375-92. [http://dx.doi.org/10.1353/hub.2003.0040] [PMID: 14527201]

[40] Sanchez-Velasco P, Gomez-Casado E, Martinez-Laso J, et al. HLA alleles in isolated populations from North Spain: Origin of the Basques and the ancient Iberians. Tissue Antigens 2003; 61(5): 384-92. [http://dx.doi.org/10.1034/j.1399-0039.2003.00041.x] [PMID: 12753657]

[41] González-Galarza FF, Takeshita LY, Santos EJ, et al. Allele frequency net 2015 update: New features for HLA epitopes, KIR and disease and HLA adverse drug reaction associations. Nucleic Acids Res 2015; 43(Database issue): D784-8. [http://dx.doi.org/10.1093/nar/gku1166] [PMID: 25414323]

[42] Martinez-Laso J, Herraiz MA, Peñaloza J, et al. Promoter sequences confirm the three different evolutionary lineages described for HLA-G. Hum Immunol 2013; 74(3): 383-8. [http://dx.doi.org/10.1016/j.humimm.2012.11.016] [PMID: 23220497]

[43] Meyer D, Thomson G. How selection shapes variation of the human major histocompatibility complex: A review. Ann Hum Genet 2001; 65(Pt 1): 1-26. [http://dx.doi.org/10.1046/j.1469-1809.2001.6510001.x] [PMID: 11415519]

[44] Arnaiz-Villena A, Enriquez-de-Salamanca M, Areces C, et al. HLA-G( $\square$ )01:05N null allele in Mayans (Guatemala) and Uros (Titikaka Lake, Peru): Evolution and population genetics. Hum Immunol 2013; 74(4): 478-82. [http://dx.doi.org/10.1016/j.humimm.2012.12.013] [PMID: 23261410] 
[45] Castelli EC, Mendes-Junior CT, Donadi EA. HLA-G alleles and HLA-G 14 bp polymorphisms in a Brazilian population. Tissue Antigens 2007; 70(1): 62-8. [http://dx.doi.org/10.1111/j.1399-0039.2007.00855.x] [PMID: 17559583]

[46] Park Y, Park Y, Kim YS, Kwon OJ, Kim HS. Allele frequencies of human leukocyte antigen-G in a Korean population. Int J Immunogenet 2012; 39(1): 39-45. [http://dx.doi.org/10.1111/j.1744-313X.2011.01053.x] [PMID: 22035429]

[47] Matte C, Lacaille J, Zijenah L, Ward B, Roger M. HLA-G exhibits low level of polymorphism in indigenous East Africans. Hum Immunol 2002; 63(6): 495-501 [http://dx.doi.org/10.1016/S0198-8859(02)00391-9] [PMID: 12039526]

[48] Hviid TV. HLA-G in human reproduction: Aspects of genetics, function and pregnancy complications. Hum Reprod Update 2006; 12(3): 209-32. [http://dx.doi.org/10.1093/humupd/dmi048] [PMID: 16280356]

[49] Arnaiz-Villena A, Enriquez-de-Salamanca M, Palacio-Grüber J, et al. Characterisation and functional implications of the two new HLA-G alleles found in Amerindian and Caribbean populations. Hum Immunol 2016; 77(9): 812-6. [http://dx.doi.org/10.1016/j.humimm.2016.01.006] [PMID: 26796363]

[50] Robinson J, Waller MJ, Parham P, Bodmer JG, Marsh SG. IMGT/HLA Database--a sequence database for the human major histocompatibility complex. Nucleic Acids Res 2001; 29(1): 210-3. [http://dx.doi.org/10.1093/nar/29.1.210] [PMID: 11125094]

[51] Vargas-Alarcón G, Gamboa R, Zuñiga J, et al. HLA-DR4 allele frequencies on Indian and Mestizo population from Mexico. Hum Immunol 2000; 61(3): 341-4. [http://dx.doi.org/10.1016/S0198-8859(99)00180-9] [PMID: 10689126]

[52] Yunis JJ, Ossa H, Salazar M, et al. Major histocompatibility complex class II alleles and haplotypes and blood groups of four Amerindian tribes of northern Colombia. Hum Immunol 1994; 41(4): 248-58. [http://dx.doi.org/10.1016/0198-8859(94)90043-4] [PMID: 7883592]

[53] Arnaiz-Villena A, Vargas-Alarcón G, Granados J, et al. HLA genes in Mexican Mazatecans, the peopling of the Americas and the uniqueness of Amerindians. Tissue Antigens 2000; 56(5): 405-16. [http://dx.doi.org/10.1034/j.1399-0039.2000.560503.x] [PMID: 11144288]

[54] Arnaiz-Villena A, Gonzalez-Alcos V, Serrano-Vela JI, et al. HLA genes in Uros from Titikaka Lake, Peru: Origin and relationship with other Amerindians and worldwide populations. Int J Immunogenet 2009; 36(3): 159-67. [http://dx.doi.org/10.1111/j.1744-313X.2009.00841.x] [PMID: 19490211]

[55] Arnaiz-Villena A, Bayona B, Palacio-Gruber J, et al. HLA genes in Barranquilla (North Colombia): Searching for cryptic Amerindian genes. Hum Immunol 79: 03-4.

[http://dx.doi.org/10.10167j.humimm.2017.11.003]

[56] Le Discorde M, Le Danff C, Moreau P, Rouas-Freiss N, Carosella ED. HLA-G*0105N null allele encodes functional HLA-G isoforms. Biol Reprod 2005; 73(2): 280-8. [http://dx.doi.org/10.1095/biolreprod.104.037986] [PMID: 15814900]

[57] Abbas A, Tripathi P, Naik S, Agrawal S. Analysis of human leukocyte antigen (HLA)-G polymorphism in normal women and in women with recurrent spontaneous abortions. Eur J Immunogenet 2004; 31(6): 275-8. [http://dx.doi.org/10.1111/j.1365-2370.2004.00487.x] [PMID: 15548266]

[58] Rahimi R, Hosseini AZ, Yari F. The polymorphism of human leucocyte antigen-G gene in a healthy population of Iran. Int J Immunogenet 2010; 37(4): 269-72. [http://dx.doi.org/10.1111/j.1744-313X.2010.00919.x] [PMID: 20477884]

[59] Jassem RM, Shani WS, Loisel DA, Sharief M, Billstrand C, Ober C. HLA-G polymorphisms and soluble HLA-G protein levels in women with recurrent pregnancy loss from Basrah province in Iraq. Hum Immunol 2012; 73(8): 811-7. [http://dx.doi.org/10.1016/j.humimm.2012.05.009] [PMID: 22651916]

[60] van der Ven K, Skrablin S, Engels G, Krebs D. HLA-G polymorphisms and allele frequencies in Caucasians. Hum Immunol 1998; 59(5): 302-12.

[http://dx.doi.org/10.1016/S0198-8859(98)00021-4] [PMID: 9619769]

[61] Di Cristofaro J, Buhler S, Frassati C, et al. Linkage disequilibrium between HLA-G*0104 and HLA-E*0103 alleles in Tswa Pygmies. Tissue Antigens 2011; 77(3): 193-200.

[http://dx.doi.org/10.1111/j.1399-0039.2010.01599.x] [PMID: 21299523]

[62] Sipak-Szmigiel O, Cybulski C, Wokołorczyk D, et al. HLA-G polymorphism and in vitro fertilization failure in a Polish population. Tissue Antigens 2009; 73(4): 348-52. [http://dx.doi.org/10.1111/j.1399-0039.2008.01205.x] [PMID: 19317745]

[63] Yan WH, Fan LA, Yang JQ, Xu LD, Ge Y, Yao FJ. HLA-G polymorphism in a Chinese Han population with recurrent spontaneous abortion. Int J Immunogenet 2006; 33(1): 55-8. [http://dx.doi.org/10.1111/j.1744-313X.2006.00567.x] [PMID: 16426245] 
[64] Ishitani A, Kishida M, Sageshima N, et al. Re-examination of HLA-G polymorphism in African Americans. Immunogenetics 1999; 49(9): 808-11.

[http://dx.doi.org/10.1007/s002510050555] [PMID: 10398808]

[65] Arnaiz-Villena A, Muñiz E, Campos C, Gomez-Casado E, Tomasi S, Martinez-Quiles N, et al. Origin of Ancient Canary Islanders (Guanches): Presence of Atlantic/Iberian HLA and Y chromosome genes and Ancient Iberian language. Int J Mod Anthrop 2015; 8: 67-93. [http://dx.doi.org/10.4314/ijma.v1i8.4]

[66] Arnaiz-Villena A, Carballo A, Juarez I, et al. HLA genes in Atlantic Celtic populations: Are Celts Iberians? Int J Mod Anthrop 2017; 10: 50-72.

[http://dx.doi.org/10.4314/ijma.v1i10.2]

[67] Degos L, Dausset J. Human migrations and linkage disequilibrium of HLA system. Immunogenetics 1974; $1: 195-210$. [http://dx.doi.org/10.1007/BF01564062]

[68] Arnaiz-Villena A, Morales P, Gomez-Casado E, et al. Evolution of MHC-G in primates: A different kind of molecule for each group of species. J Reprod Immunol 1999; 43(2): 111-25. [http://dx.doi.org/10.1016/S0165-0378(99)00026-1] [PMID: 10479048]

[69] Aldrich C, Wambebe C, Odama L, Di Rienzo A, Ober C. Linkage disequilibrium and age estimates of a deletion polymorphism (1597DeltaC) in HLA-G suggest non-neutral evolution. Hum Immunol 2002; 63(5): 405-12. [http://dx.doi.org/10.1016/S0198-8859(02)00377-4] [PMID: 11975984]

[70] Lajoie J, Hargrove J, Zijenah LS, Humphrey JH, Ward BJ, Roger M. Genetic variants in nonclassical major histocompatibility complex class I human leukocyte antigen (HLA)-E and HLA-G molecules are associated with susceptibility to heterosexual acquisition of HIV-1. J Infect Dis 2006; 193(2): 298-301. [http://dx.doi.org/10.1086/498877] [PMID: 16362895]

[71] Yamashita T, Fujii T, Watanabe Y, et al. HLA-G gene polymorphism in a Japanese population. Immunogenetics 1996; 44(3): 186-91. [http://dx.doi.org/10.1007/BF02602584] [PMID: 8662085]

[72] Park KS, Park JS, Nam JH, Bang D, Sohn S, Lee ES. HLA-E*0101 and HLA-G*010101 reduce the risk of Behcet's disease. Tissue Antigens 2007; 69(2): 139-44. [http://dx.doi.org/10.1111/j.1399-0039.2006.00742.x] [PMID: 17257316]

[73] Matte C, Lacaille J, Zijenah L, Ward B, Roger M. HLA-G and HLA-E polymorphisms in an indigenous African population. Hum Immunol 2000; 61(11): 1150-6. [http://dx.doi.org/10.1016/S0198-8859(00)00200-7] [PMID: 11137220]

[74] Pirri A, Contieri FC, Benvenutti R, Bicalho MdaG. A study of HLA-G polymorphism and linkage disequilibrium in renal transplant patients and their donors. Transpl Immunol 2009; 20(3): 143-9. [http://dx.doi.org/10.1016/j.trim.2008.09.012] [PMID: 18926911]

[75] Hviid TV, Meldgaard M, Sørensen S, Morling N. Polymorphism of exon 3 of the HLA-G gene. J Reprod Immunol 1997; 35(1): 31-42. [http://dx.doi.org/10.1016/S0165-0378(97)00051-X] [PMID: 9373856]

[76] Steffensen R, Christiansen OB, Bennett EP, Jersild C. HLA-E polymorphism in patients with recurrent spontaneous abortion. Tissue Antigens 1998; 52(6): 569-72. [http://dx.doi.org/10.1111/j.1399-0039.1998.tb03088.x] [PMID: 9894856]

[77] Ober C, Rosinsky B, Grimsley C, van der Ven K, Robertson A, Runge A. Population genetic studies of HLA-G: allele frequencies and linkage disequilibrium with HLA-A1. J Reprod Immunol 1996; 32(2): 111-23. [http://dx.doi.org/10.1016/S0165-0378(96)01000-5] [PMID: 9023816]

[78] Shao W, Yoo Y, Tang J, Zhang K, Allen S, Kaslow R. Tight linkage disequilibrium between HLA-G and HLA-A alleles in native Africans. Hum Immunol 2006; 67: S118. [http://dx.doi.org/10.1016/j.humimm.2006.08.180]

[79] Alvarez M, Santos P, Martinho A, Simões O, Abade A, Brêda-Coimbra H. HLA-G genetic polymorphism in 57 Portuguese white families studied by PCR-RFLP and PCR-SSOP. Transplant Proc 1999; 31(4): 1829-31. [http://dx.doi.org/10.1016/S0041-1345(99)00179-7] [PMID: 10371964]

(C) 2018 Arnaiz-Villena et al.

This is an open access article distributed under the terms of the Creative Commons Attribution 4.0 International Public License (CC-BY 4.0), a copy of which is available at: https://creativecommons.org/licenses/by/4.0/legalcode. This license permits unrestricted use, distribution, and reproduction in any medium, provided the original author and source are credited. 